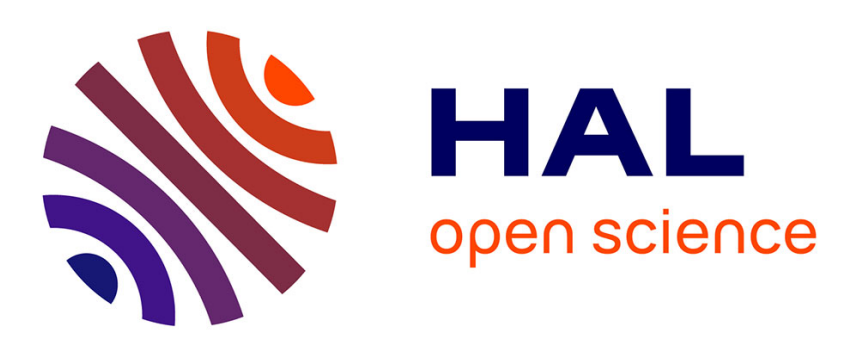

\title{
Discourse Particles In French: Prosodic Parameters Extraction and Analysis
}

Mathilde Dargnat, Katarina Bartkova, Denis Jouvet

\section{To cite this version:}

Mathilde Dargnat, Katarina Bartkova, Denis Jouvet. Discourse Particles In French: Prosodic Parameters Extraction and Analysis. International Conference on Statistical Language and Speech Processing, Nov 2015, Budapest, Hungary. hal-01184197

\section{HAL Id: hal-01184197 https://hal.inria.fr/hal-01184197}

Submitted on 13 Aug 2015

HAL is a multi-disciplinary open access archive for the deposit and dissemination of scientific research documents, whether they are published or not. The documents may come from teaching and research institutions in France or abroad, or from public or private research centers.
L'archive ouverte pluridisciplinaire HAL, est destinée au dépôt et à la diffusion de documents scientifiques de niveau recherche, publiés ou non, émanant des établissements d'enseignement et de recherche français ou étrangers, des laboratoires publics ou privés. 


\title{
Discourse Particles In French: Prosodic Parameters Extraction and Analysis
}

\author{
Mathilde Dargnat ${ }^{1}$, Katarina Bartkova ${ }^{1}$, and Denis Jouvet ${ }^{2}$ \\ 1 Université de Lorraine \& CNRS, ATILF, UMR 7118 \\ 44, avenue de la Libération BP 30687 - F-54063 Nancy Cedex France \\ \{mathilde.dargnat, katarina.bartkova\}@atilf.fr \\ 2 Speech Group, LORIA \\ Inria, Villers-lès-Nancy, F-54600, France \\ Université de Lorraine, LORIA, UMR 7503, Villers-lès-Nancy, F-54600, France \\ CNRS, LORIA, UMR 7503, Villers-lès-Nancy, F-54600, France \\ denis.jouvet@inria.fr
}

\begin{abstract}
Detecting the correct syntactic function of a word is of great importance for language and speech processing. The semantic load of a word is different whether its function is a discourse particle or a preposition. Words having the function of a discourse particle (DP) are very frequent in spontaneous speech and their discursive function is often expressed only by prosodic means. Our study analyses some prosodic correlates of two French words (quoi, voilà), used as discourse particles or pronoun (quoi) or preposition (voilà). Our goal is to determine to what extent intrinsic and contextual prosodic properties characterize DP and nonDP functions. Prosodic parameters are analyzed with respect to the DP or non-DP function for these words extracted from large speech corpora. A preliminary test concerning the automatic detection of the word function is also carried out using prosodic parameters only, leading to an encouraging result of $70 \%$ correct identification.
\end{abstract}

Keywords: part-of-speech tagging, prosody, discourse particles, discourse structure, automatic prosodic annotation

\section{Introduction}

The correct category definition of homographic lexical units often determine their phonetic forms, stressed syllable or prosodic characteristics. But a word can also have different pragmatic properties which can impact the word semantic load. A word with low semantic content is often considered as a disturbance of the speech fluency and can then disappear in automatic processing (content retrieval, automatic translation ... ). Therefore it becomes important to detect the syntactic and pragmatic properties of the words and, for a correct detection of these properties, the lexical context is sometimes not enough, prosodic information is also needed. The aim of this study is to investigate how the pragmatic properties of words can trigger different prosodic parameters. This study is part of a larger 
project on discourse particles (DP) in French [2]. It aims to correlate DP's prosodic properties with their syntactical, semantic and pragmatic properties. In this paper, we focus here on the prosodic analysis of two words, quoi (what) and voilà (here is, that's it, there), frequently used as DP in formal and casual speech, and we mainly examine the relevance of some prosodic features in distinguishing between DP and non-DP use of these words.

Studies generally address DP through semantic and pragmatic descriptions, from synchronic or diachronic points of view (see $[30,24,6,13,22,5])$. Syntactic analysis is less frequent (see $[10,29,17])$, while prosodic considerations remain peripheral or too general (see $[31,11,1]$ ). The goal of our study is to construct a fine-grained corpus-based prosodic analysis, in order to identify possible correlations with other linguistic properties of DP. The main question addressed here concerns the correlation between syntactic properties (mainly position in the utterance) and discourse values (information structure) on the one hand, and prosodic features (pause, position in prosodic group, syllabic duration, tone, slope ...) on the other hand. If such a correlation is confirmed, this could lead to an interesting tool for distinguishing different uses of the studied items (e.g. quoi as a pronoun or as a DP, and its different values as DP: closing, rhematic marker, reformulation, etc.).

\section{Discourse Particles}

DP convey information about utterance interpretation, epistemic state and affective mood of the speaker or the management of interaction [13]. DP do not form parts of speech like verbs or adjectives (contra Paillard [25]), but a 'functional category' $[24,15]$ whose lexical members, in addition to being DP, have more traditional grammatical uses, like coordinating conjunctions, adverbs, verbs, pronouns, interjections, adjectives. We focus here on major grammatical and discursive uses of quoi (pronoun vs. DP) and voilà (preposition, introducer [18] vs. DP) in French. We do not propose for the moment a more fine-grained sub-categorization.

\subsection{Main features}

DP frequently exhibit phonetic attrition. They have prosodic autonomy and can be singled out by a pause or a specific prosodic pattern (see $[20,21,14,1]$ ). In French, they tend to be mono- or bisyllabic, but some of them are also 'complex', i.e., combinations like 'bon ben quoi voilà hein', 'mais enfin' or 'écoutez donc'. DP are neither argument nor circumstantial adjuncts. They are optional and their position in the utterance is neither fixed nor totally free (see $[9,27,16,13,24])$. DP do not contribute to the propositional content of the utterance. As a result, they do not affect its truth value. They have undergone a 'pragmaticalization' process whereby their initial meaning has given way to some pragmatic or 'procedural' values [28] (for DP main feature descriptions, see also [6,13,14,12,2]) 


\subsection{Illustration: quoi and voilà}

The words quoi and voilà have been chosen because they are very frequent in present-day French. They belong to different parts of speech, they occur in several positions and they play a role in discourse information structuring. Major DP values of quoi are closing, leftward focus marking (1), (re)phrasing signaling with a specificity to refer to the previous context (it has scope over the material to its left) (See $[8,12,22,23])$. Major DP values of voilà are closing, sometimes with agreement expression about the previous discourse, and stage marking in an ongoing non-linguistic activity (2). Its position depends on its pragmatic values and on the discourse type (monologue vs. dialogue) $[6,7]$.

(1) c'est un outil de travail mais c'est de l'abstrait quoi c'est c'est it's a working tool but it's abstract PARTICLE, it's it's c'est pas du concret quoi

it's not concrete PARTICLE

'It's a working tool, but an abstract one PARTICLE, it's it's it's not concrete PARTICLE'

[22, p. 6]

c'est bon allez: $\downarrow$ on va mouiller $\downarrow$ voilà: $\quad$ vous remuez
it's OK go, we are gonna get wet PARTICLE: you stir
'It's OK, we will get wet, that's it: move'
[6, p. 366$]$

\section{Methodology and corpus}

The study of the prosodic parameters of our DP words is corpus-based. The major part of our data processing is done automatically. An effort was made to build an automatic extraction and annotation procedure that will further allow enrichment of our DP database in a consistent way. However, manual intervention is still needed to distinguish between DP or non-DP uses. We kept only occurrences for which at least two expert annotators agreed.

\subsection{Corpus constitution and extraction}

All occurrences of voilà and quoi are extracted from the ESTER corpus (French broadcast news collected from various radio channels, about 200 hours of speech) and from the ETAPE corpus (debates collected from various French radio and TV channels, about 30 hours of recordings). Their compositions slightly differ: ETAPE contains more spontaneous speech whereas ESTER is mainly constituted of broadcast news and includes relatively few interviews. An advantage in using such corpora is the rather good quality of the speech signal, which leads to a reliable acoustic analysis. Table 1 indicates the distribution of DP vs. non-DP uses of the two words, after manual annotation. As illustrated in Table 1, there is quite a difference between the DP uses of the two words studied here, in fact the DP use of voilà is almost twice as high as the DP use of quoi. 
Table 1. Distribution of DP and non-DP uses (and number of occurrences) for the words voilà and quoi in ESTER and ETAPE corpora

\begin{tabular}{|c|c|c|c|}
\hline & Number of occurrences & DP & Non-DP \\
\hline quoi & 1002 & $381 \Rightarrow 39 \%$ & $621 \Rightarrow 61 \%$ \\
\hline voilà & 1407 & $971 \Rightarrow 69 \%$ & $436 \Rightarrow 31 \%$ \\
\hline
\end{tabular}

\subsection{Speech data pre-processing}

ESTER and ETAPE contain manual transcriptions and information of different types (speakers, turn-takings, dysfluencies, noise, etc.). All the speech data processing is done automatically. First, grapheme-to-phoneme translation is carried out and the sound segmentation is achieved, using forced alignment (achieved with Sphinx tools). Subsequently, Prosotran annotator [3] is used, which, for each vowel, indicates the degree of its duration lengthening (compared to a mean vowel duration calculated on at least 5 adjacent syllables); its F0 slope, compared to the glissando threshold; its pitch level, quantized on a ten level scale calculated on the whole speaker data. Further prosodic information is provided by the detection of prosodic groups. Segmentation of the speech stream into prosodic groups is yielded by the ProsoTree software [4], which locates intonation group boundaries using information based on F0 slope values, pitch level and vowel duration (Figure 1).

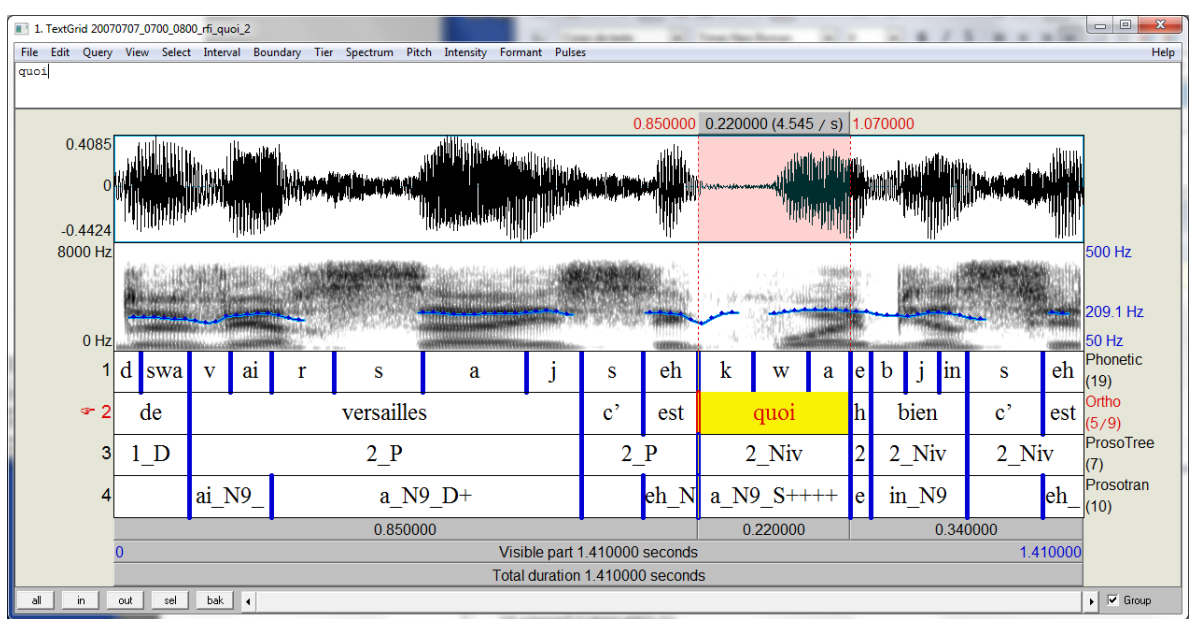

Fig. 1. Result of prosodic processing of speech data using Prosotran and Prosotree software 


\section{Analysis of results}

As mentioned before, we investigate here whether intrinsic and contextual prosodic properties are reliable cues to characterize DP and non-DP uses of voilà and quoi, either separately or jointly. In this section, we analyze and discuss for the studied words the role of pauses preceding or following them, their pitch level in isolation and in relation to their immediate preceding and following contexts, their vowel duration, whose lengthening may indicate a stressed position and their position in the intonation group.

\subsection{Pauses}

Information about pauses are collected automatically. The occurrences of pause contexts are presented in Table 2. Some pauses whose durations have not been measured (they occur before the first or after the last word of the speech segment) do not appear in Table 2.

Several differences in pause occurrences are noteworthy:

- Non-DP uses: quoi occurs predominantly without a pause; if voilà occurs with a pause, the pause is predominantly before, with a big proportion of long pauses (>250 ms).

- DP and non-DP uses: when quoi occurs with a pause, this pause comes pre-dominantly after, with a large proportion of long pauses $(>250 \mathrm{~ms})$ for DP uses.

These pause occurrences correspond to syntactical and information structures of the non-DP and DP uses: non-DP quoi is often an argument of a verb, DP $q u o i$ is more often conclusive. Non-DP voilà begins an utterance and, as an introducer or a preposition, introduces the following discourse segment, which is syntactically dependent on it.

\subsection{Position in the intonation group}

The position of quoi and voilà in the intonation groups (IG) is analysed according to the intonation groups automatically detected using the Prosotree software. Results about their location in the intonation group are displayed in Figure 2.
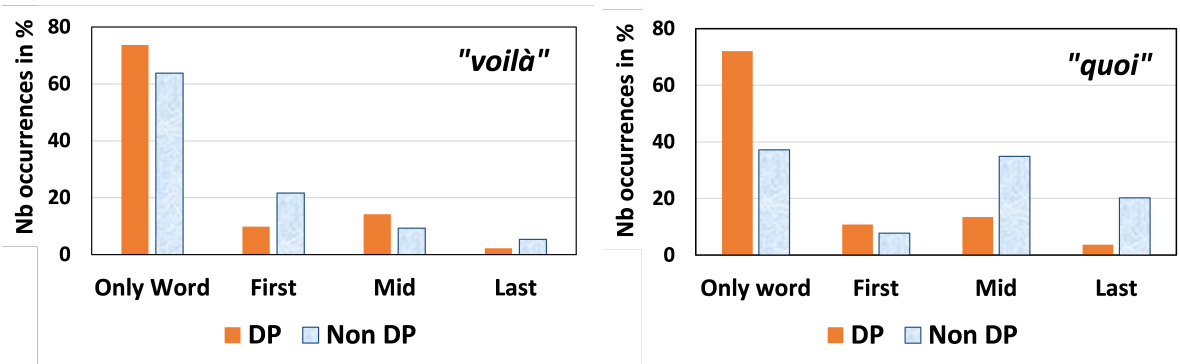

Fig. 2. Position of voilà and quoi in the intonation groups 
Table 2. Number of pauses before and after quoi and voilà: number of occurrences (in parentheses) and percentage per category.(short $\leq 100 \mathrm{~ms}$; mid $\leq 250 \mathrm{~ms}$; long $\geq 250 \mathrm{~ms}$ ).

\begin{tabular}{|c|c|c|c|c|c|c|c|c|}
\hline & & \multicolumn{6}{|c|}{ Pauses } & \multirow{3}{*}{$\begin{array}{c}\text { No } \\
\text { pause }\end{array}$} \\
\hline & & \multicolumn{3}{|c|}{ Before } & \multicolumn{3}{|c|}{ After } & \\
\hline & & short & mid & long & short & mid & long & \\
\hline \multirow{2}{*}{ quoi } & $\begin{array}{l}\text { DP } \\
(399)\end{array}$ & $\begin{array}{c}1.2 \% \\
(5)\end{array}$ & $\begin{array}{c}\mathbf{5 . 0 \%} \\
(20)\end{array}$ & $\begin{array}{c}0.2 \% \\
(1)\end{array}$ & $\begin{array}{c}\mathbf{5 . 7 \%} \\
(23)\end{array}$ & $\begin{array}{l}\mathbf{1 4 \%} \\
(55)\end{array}$ & $\begin{array}{c}40.0 \% \\
(160)\end{array}$ & $\begin{array}{c}\mathbf{3 4 . 0 \%} \\
(135)\end{array}$ \\
\hline & $\begin{array}{c}\text { Non-DP } \\
(630)\end{array}$ & $\begin{array}{c}\mathbf{0 . 7 \%} \\
(3)\end{array}$ & $\begin{array}{c}\mathbf{4 . 0 \%} \\
(25)\end{array}$ & $\begin{array}{l}3.0 \% \\
(19)\end{array}$ & $\begin{array}{c}\mathbf{5 . 0 \%} \\
(32)\end{array}$ & $\begin{array}{c}\mathbf{8 . 6 \%} \\
(54)\end{array}$ & $\begin{array}{c}12.0 \% \\
(78)\end{array}$ & $\begin{array}{c}\mathbf{6 6 . 5 \%} \\
(419)\end{array}$ \\
\hline \multirow{2}{*}{ voilà } & $\begin{array}{c}\text { DP: } \\
\text { (1019) }\end{array}$ & $\begin{array}{c}0.4 \% \\
(4)\end{array}$ & $\begin{array}{c}\mathbf{1 1 . 2 \%} \\
(114)\end{array}$ & $\begin{array}{c}\mathbf{2 0 . 2 \%} \\
(206) \\
\end{array}$ & $\begin{array}{c}10.0 \% \\
(103)\end{array}$ & $\begin{array}{r}11.6 \% \\
(118) \\
\end{array}$ & $\begin{array}{c}\mathbf{2 3 . 0 \%} \\
(232)\end{array}$ & $\begin{array}{r}\mathbf{2 3 . 7 \%} \\
(242) \\
\end{array}$ \\
\hline & $\begin{array}{c}\text { Non-DP } \\
\text { (416) }\end{array}$ & $\begin{array}{c}\mathbf{0 . 5 \%} \\
(2)\end{array}$ & $\begin{array}{c}7.2 \% \\
(30)\end{array}$ & $\begin{array}{c}\mathbf{3 5 . 6 \%} \\
(148)\end{array}$ & $\begin{array}{c}3.3 \% \\
(14)\end{array}$ & $\begin{array}{c}\mathbf{4 . 1 \%} \\
(17)\end{array}$ & $\begin{array}{c}4.3 \% \\
(18)\end{array}$ & $\begin{array}{r}\mathbf{4 5 . 0 \%} \\
(187)\end{array}$ \\
\hline
\end{tabular}

According to our results, quoi and voilà more frequently occur as single words in their corresponding intonation group, but relevant distinctions can be made when they are integrated into a larger IG.

DP quoi occurs predominantly as a single word. Its prosodic detachment is coherent with its syntactical and semantical relative autonomy. Non-DP quoi occurs as a single word, but in equal proportion in middle position in IG. The intermediate position seems to be an indicator of its syntactic and semantic integration.

DP voilà occurs predominantly as a single word too, for the same reason as DP quoi. Non-DP voilà, in contrast to non-DP quoi, occurs preferentially at the beginning and not in an intermediate position. This corroborates it 'openingintroducing' function.

\subsection{Pitch level and F0 slope}

Pitch level values of the syllable nuclei are yielded by the Prosotran software, quantized on a ten degree scale. In order to compare pitch levels for voilà and quoi in our data, only measurements on the last syllable (last nuclei) are used.

As illustrated in Figure 3, DP quoi is uttered very often at low pitch levels and very seldom at high pitch levels. It confirms its major conclusive function. On the other hand, voilà is often uttered at high pitch level.

\subsection{Fo slopes linking with left and right contexts}

The prosodic articulation between voilà and quoi and their neighbour words is measured by F0 slope values. The slope between voilà or quoi and its left 

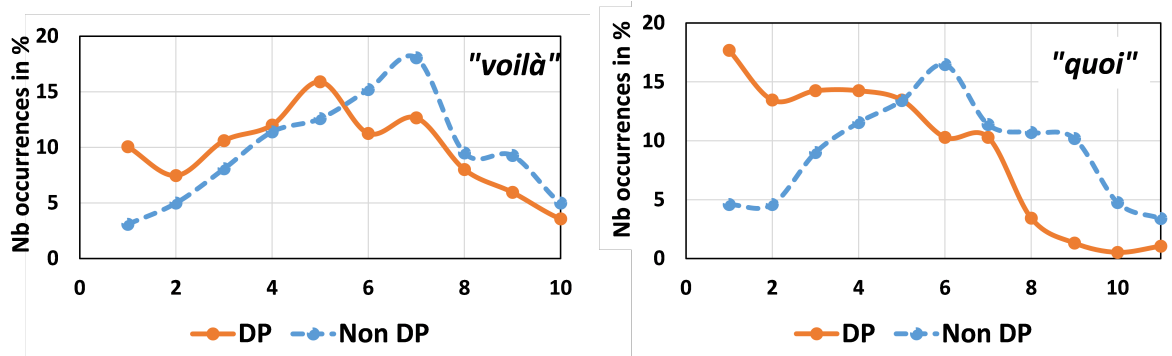

Fig. 3. Frequency of occurrences with respect to pitch level values (measured on the last syllable nuclei)

context corresponds to the $\Delta \mathrm{F} 0$ between the first (or unique) syllable of quoi or voilà and the last syllable of the previous word (a negative slope means that the quoi or voilà target syllable has a lower F0 value than the last syllable of the previous word). The slope with respect to the right context is obtained as the $\Delta \mathrm{F} 0$ between the first syllable of the next word and the last or only syllable of voilà and quoi (a negative slope means that the quoi or voilà target syllable has a higher F0 value than the first syllable of the next word).

For quoi as DP (see Figure 4), the F0 slope has often a falling pattern in relation to its left context. The DP is generally added at the end of a sentence as a kind of 'pronounced comma' and its F0 level is most of the time low or very low.

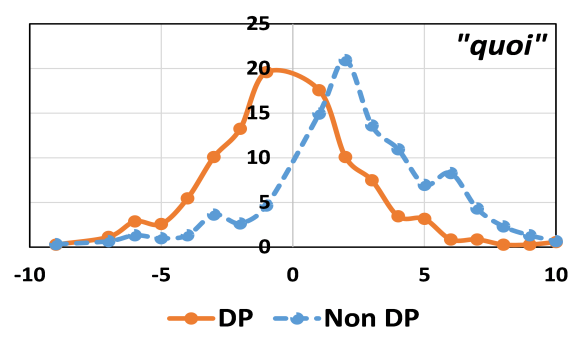

quoi, left context slope

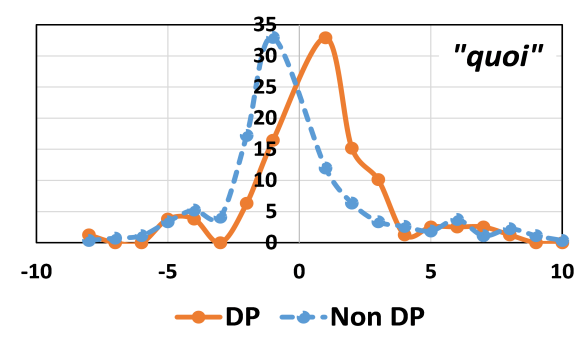

$\boldsymbol{q u o i}$, right context slope

Fig. 4. Frequency of occurrences with respect to the $\Delta \mathrm{F} 0$ value for quoi

With respect to the $\mathrm{F} 0$ slopes, the $\mathrm{DP}$ voila has a similar behaviour as the DP quoi, since it is often used as a conclusive particle. However, its F0 pattern is different from the particle quoi. In fact, (see Figure 5), this particle can be uttered with a conclusive (falling) but also with a continuative (rising) F0 pattern. This observation is corroborated also by its pitch level characteristics (see Figure 3). 


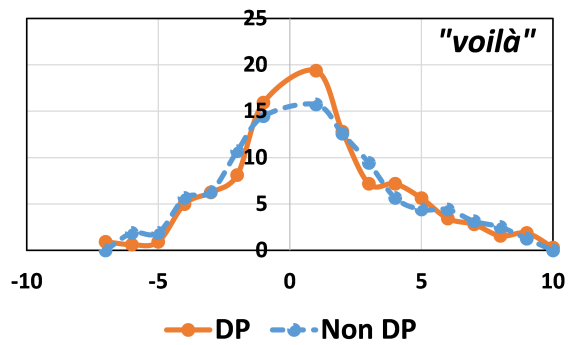

voilà, left context slope

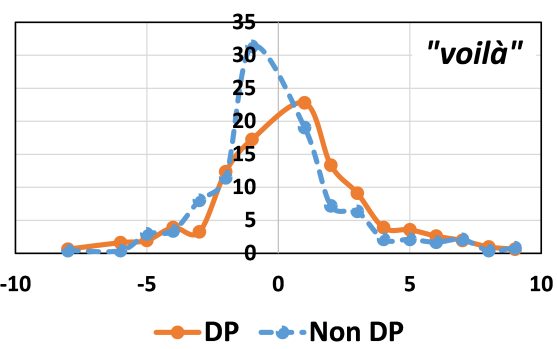

voilà, right context slope

Fig. 5. Frequency of occurrences with respect to the $\Delta \mathrm{F} 0$ value for voilà

\subsection{Vowel duration}

Prosotran provides information about vowel duration, which includes three symbolic annotation degrees of vowel lengthening: very strong, strong and mild lengthening (see respectively $\mathrm{D}+++, \mathrm{D}++$ and $\mathrm{D}+$ in Table 3 and Figure 6). This annotation is used for comparing duration lengthening of the last (or unique) vowels of the words. As vowel duration lengthening is a strong parameter cue for stressed syllable in French, it seems worthwhile to analyse how vowel duration lengthening contributes to the prosodic characteristics of the DP. Table 3 and Figure 6 show the number of occurrences and the percentage of lengthened vowels for both words, in their DP and non-DP uses.

Table 3. quoi and voilà last syllable duration, percentage of occurrences according to vowel lengthening, and number of occurrences in parentheses

\begin{tabular}{|l|l|c|c|c|c|}
\hline \multicolumn{2}{|c|}{} & \multirow{2}{*}{$\begin{array}{c}\text { no lengthening } \\
\text { detected } \\
\text { D }\end{array}$} & \multicolumn{2}{|c|}{ Degree of lengthening of word last syllable } \\
\cline { 4 - 6 } \multicolumn{2}{c|}{} & & D+ & D++ & D+++ \\
\hline \multirow{2}{*}{ quoi } & DP & $\begin{array}{c}80.0 \% \\
(305)\end{array}$ & $\begin{array}{c}9.7 \% \\
(37)\end{array}$ & $\begin{array}{c}6.0 \% \\
(23)\end{array}$ & $\begin{array}{c}4.2 \% \\
(16)\end{array}$ \\
\cline { 2 - 6 } & Non-DP & $\begin{array}{c}81.3 \% \\
(505)\end{array}$ & $\begin{array}{c}9.7 \% \\
(60)\end{array}$ & $\begin{array}{c}3.4 \% \\
(21)\end{array}$ & $\begin{array}{c}5.6 \% \\
(35)\end{array}$ \\
\hline \multirow{2}{*}{ voilà } & DP & $\begin{array}{c}65.0 \% \\
(632)\end{array}$ & $\begin{array}{c}15.0 \% \\
(146)\end{array}$ & $\begin{array}{c}9.9 \% \\
(96)\end{array}$ & $\begin{array}{c}10.0 \% \\
(97)\end{array}$ \\
\cline { 2 - 6 } & Non-DP & $\begin{array}{c}85.5 \% \\
(373)\end{array}$ & $\begin{array}{c}8.9 \% \\
(39)\end{array}$ & $\begin{array}{c}2.7 \% \\
(12)\end{array}$ & $\begin{array}{c}2.7 \% \\
(12)\end{array}$ \\
\hline
\end{tabular}



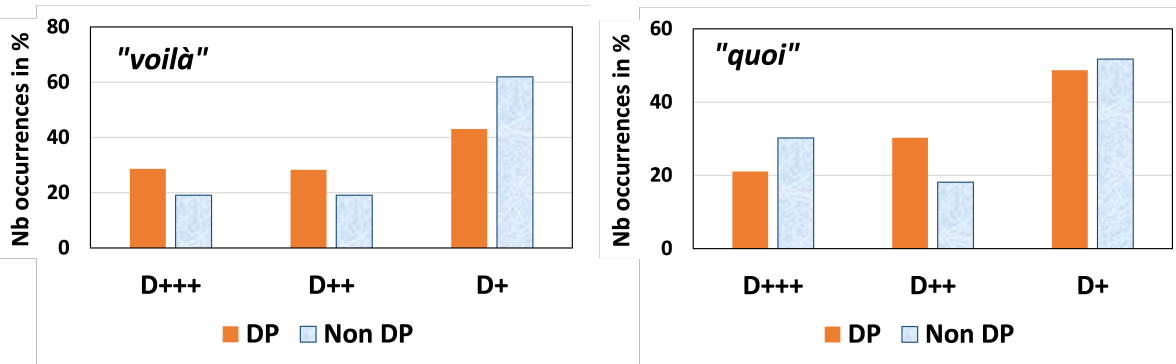

Fig. 6. quoi and voilà, last syllable vowel lengthening (percentage of the lengthened vowels)

Statistics in Table 3 show that for each sub-category, the target vowel is predominantly non-lengthened. However, if we analyse only the cases with lengthening (see Figure 6), we can observe that:

- The lengthening for voilà is more important when used as a DP than in a non-DP function;

- With respect to the strongest lengthening $(\mathrm{D}+++)$, quoi and voilà do not behave in the same way: DP voilà is more often markedly lengthened than non-DP voilà, contrary to DP quoi, which is less often markedly lengthened than non-DP quoi.

\subsection{Automatic DP identification}

An automatic identification of the DP function for the two words under study was carried out. The identification procedure relies only on the prosodic parameters described and analysed in the previous paragraphs.

We used the j48 decision tree [26] in the Weka toolkit [19]. The use of a decision tree is motivated by the adequacy of this technique for data which contain numeric and symbolic values. The decision tree is trained on $60 \%$ of our data while the remaining $40 \%$ is kept for evaluating the classifier (identification of the DP function).

The results obtained by the classifier (see Table 4) are very encouraging. In fact, in more than $70 \%$ of the cases, the DP function is correctly identified using prosodic parameters only. Thus, one can reasonably expect a substantial improvement of these results when more linguistic information (part of speech ... ) is introduced into the decision procedure. 
Table 4. DP automatic identification scores in percentage

\begin{tabular}{|c|c|c|c|c|}
\hline & $\begin{array}{c}\text { Correct } \\
\text { identification }\end{array}$ & Precision & Recall & F-Measure \\
\hline quoi & $\underline{\mathbf{7 1 \%}}$ & $71 \%$ & $71 \%$ & $71 \%$ \\
\hline voilà & $\underline{\mathbf{7 3} \%}$ & $73 \%$ & $73 \%$ & $73 \%$ \\
\hline
\end{tabular}

\section{Conclusion}

Our study aims to identify pertinent prosodic parameters associated to two French words (quoi and voilà) when used as a discourse particle (DP function) or not (i.e., pronoun, preposition, ...).

The identification of the DP function of the words is very important for the automatic processing of speech data. For example, the translation of such words will be different whether they have a DP function or a non-DP function. It can be sometimes hard to retrieve the DP function from the written form only and other complementary information is also needed to identify correctly these discourse functions. It is found in this study, that the DP function can be successfully identified using prosodic parameters. In fact, our preliminary automatic identification of the DP functions of the studies words yielded very encouraging results: more than $70 \%$ of the word functions are correctly identified.

\section{References}

1. Aijmer, K.: Understanding Pragmatic Markers, A Variational Pragmatic Approach. Edinburgh University Press, Edinburgh (2013)

2. Bartkova, K., Dargnat, M.: Pardi!: Particules discursives: sens et corrélats prosodiques (2014-2015), ATILF Research Project

3. Bartkova, K., Delais-Roussarie, E., Santiago, F.: Prosotran: a tool to annotate prosodically non-standard data. In: Proceedings of Speech Prosody 2012, Shangaï. pp. 55-58 (2012)

4. Bartkova, K., Jouvet, D.: Automatic detection of the prosodic structures of speech utterances. In: Proceedings of SPECOM-15th, International Conference on Speech and Computer. pp. 1-8. Springer, Berlin (2013)

5. Beeching, K.: La co-variation des marqueurs discursifs bon, c'est-à-dire, enfin, hein, quand même, quoi et si vous voulez: une question d'identité ? Langue Française 154, 78-93 (2007)

6. Brémond, C.: Les "petites marques du discours". Le cas du marqueur méta-discursif bon en français. Ph.D. thesis, Dpt. of Linguistics, Université de Provence (2002)

7. Bruxelles, S., Traverso, V.: Usages de la particule 'voilà' dans une réunion de travail: analyse multimodale. In: Drescher, M., Job, B. (eds.) Les marqueurs discursifs dans les langues romanes: approches théoriques et méthodologiques, pp. 71-92. Peter Lang, Bern (2006) 
8. Chanet, C.: 1700 occurrences de la particule quoi en français parlé contemporain: approches de la "distribution" et des fonctions en discours. Marges Linguistiques 2, 52-80 (2001)

9. Dargnat, M.: Marqueurs de discours et interjections. In: Abeillé, A., Godard, D. (eds.) La Grande Grammaire du Français. Actes Sud, Arles (2016), to appear

10. Degand, L., Fagard, B.: Alors between discourse and grammar: The role of syntactic position. Function of Language 18, 19-56 (2011)

11. Degand, L., Simon, A.: L'analyse des unités discursives de base: pourquoi et comment? Langue Française 170, 45-59 (2011)

12. Denturck, E.: Étude des marqueurs discursifs, l'exemple de quoi. Master's thesis, Taal-en-Letterkunde, Universiteit Gent (2008)

13. Dostie, G.: Pragmaticalisation et marqueurs discursifs. Analyse sémantique et traitement lexicographique. De Boeck-Duculot, Bruxelles (2004)

14. Dostie, G., Pusch, C.: Les marqueurs discursifs. présentation. Langue Française 154, 3-12 (2001)

15. Fernandez-Vest, J.: Les particules énonciatives dans la construction du discours. Presses Universitaires de France, Paris (1994)

16. Fraser, B.: What are discourse markers? Journal of Pragmatics 37, 931-952 (1999)

17. Gardent, C.: Syfrap project (syntaxe du français parlé) (2011-2013), LORIA-ATILFLLF Research Project

18. Grevisse, M., Goose, A.: Le Bon Usage. De Boeck-Duculot, Bruxelles, 14th edn. (2008)

19. Hall, M., Frank, E., Holmes, G., Pfahringer, B., Reutemann, P., Witten, I.H.: The weka data mining software: An update. SIGKDD Explorations 11(1) (2009), http://www.cs.waikato.ac.nz/ml/index.html

20. Hirschberg, J., Litman, D.: Empirical studies on desambiguisation of cue phrases. Computational Linguistics 19, 501-530 (1993)

21. Horne, M.P., Hansson, P., Bruce, G., Frid, J., Filipsson, M.: Cue words and the topic structure of spoken discourse: The case of Swedish men. Journal of Pragmatics 33, 1061-1081 (2001)

22. Lefeubvre, F., Morel, M.A., Teston-Bonnard, S.: Valeurs prototypiques de quoi à travers ses usages en français oral (2013), unpublished MS., Archives ouvertes HAL-SHS, https://halshs.archives-ouvertes.fr/halshs-00840728

23. Martin, P.: Quoi peut être dedans ou dehors du noyau macro-syntaxique, quoi. Unpublished (2014), handout Journée Pardi!, ATILF, Nancy, December 18-19, 2014

24. Mosegaard Hansen, M.B.: The Function of Discourse Particles. A study with Special reference to Spoken Standard French. Benjamins, Amsterdam (1998)

25. Paillard, D.: Les mots du discours comme mots de langu. Le Gré des Langues 14, 10-41 (1998)

26. Quinlan, J.R.: C4.5: Programs for Machine Learning. Morgan Kaufmann Publishers, San Mateo (1993)

27. Shiffrin, D.: Discourse markers: Language, meaning, and context. In: Shiffrin, D., Tannen, D., Hamilton, H.E. (eds.) The Handbook of Discourse Analysis, pp. 54-75. Blackwell, Oxford (2001)

28. Sperber, D., Wilson, D.: Relevance: Communication and Cognition. Blackwell, Oxford (1986)

29. Teston-Bonnard, S.: Propriétés topologiques et distributionnelles des constituants non régis. Ph.D. thesis, Dpt. of Linguistics, Université de Provence (2006)

30. Vincent, D.: Les ponctuants de la langue et autres mots du discours. Nuits Blanches, Québec (1993) 
31. Wichmann, A., Simon-Vandenbergen, A.A., Aijmer, K.: How prosody reflects semantic change: A synchronic case study of of course. In: Davidse, K., Vandelanotte, L., Cuyckens, H. (eds.) Subjectification, Intersubjectification and Grammaticalization, pp. 103-154. Mouton de Gruyter, Berlin (2010) 